\title{
The pathogenicity of different Botrytis cincrea Pers. isolates to apples and their sensitivity to benzimidazole fungicides
}

\author{
HANNA BRYK
}

Institute of Pomology and Floriculture, ul. Pomologiczna 18, 96-100 Skierniewice, Poland

(Received: September 26, 1984)

\begin{abstract}
The pathogenicity of 80 isolates of Botrytis cinerea Pers. from different hosts to apple fruit was examined. Host specificity among isolates was not found. All of the isolates, independent of their derivation, caused apple fruit rot. Isolates from apple fruits showed moderate and strong pathogenicity to apple fruits. Only 1 of the 22 examined isolates showed weak pathogenicity. Tolerance to benomyl was compared among isolates obtained from apple fruits and from other hosts. It was found that $35 \%$ of isolates from apples showed resistance to benomyl. There was no correlation between the pathogenicity of isolates and their resistance to benomyl.
\end{abstract}

\section{INTRODUCTION}

The fungus Botrytis cinerea Pers. (perfect stage Botryotinia fuckeliana (de Bary/Whetzel) is a typical polyphagous fungus. It is also the cause of apple rot during storage.

There is no uniform opinion in literature of the parasitic specialization of Botrytis cinerea Pers. M a r r a s (1960) and D u b o s and B u 1 i t (1973) found a certain kind of parasitic specialization. The fungus isolated from the grapevine was more pathogenic to grapevines than that isolated from other plants. $\mathrm{M}$ a c N e i l (1953) observed an unusual case of pathogenic specialization of Botrytis cinerea Pers. in respect to organs of the same plant. An isolate from lettuce was extremely pathogenic to lettuce roots and very weakly pathogenic to its foliage. Differentiation of pathogenicity of Botrytis cinerea Pers., in respect to the tomato was demonstrated by I $1 \mathrm{e} v$ a (1977). On the other hand however, $\mathrm{S} \mathrm{ch} \mathrm{ne} 11 \mathrm{~h} \mathrm{a} \cdot \mathrm{d} \mathrm{t}$ and $\mathrm{He}$ a $\mathrm{ld}$ (1936), P e y e r (1963) and S a d o w s k i (1971) did not find differences in the pathogenicity of Botrytis cinerea isolated from different plants.

Aside from differences in pathogenicity of the fungus, the formation of strains reacting differently to fungicides is also of great significance. The most common 
cases of resistance of Botrytis cinerea Pers. concern benzimidazole fungicides. In the years 1972-73 in Poland, sporadic cases of resistance on raspberries and strawberries were observed, in later years, resistant forms of the fungus were found very often on different plants (A r s e $\mathrm{n} \mathrm{i} \mathrm{u} \mathrm{k}$ and B r y k, 1978). There is very little information in literature on resistant forms of this fungus found on apples. G r i m m (1977) and G j a e r u m (1978) isolated strains of this fungus resistant to benzimidazoles from rotten apples whereas $\mathrm{B}$ e $\mathrm{r} \mathbf{t} \mathrm{r}$ a n d and $\mathrm{S}$ a u $\mathrm{l}$ i e-C a r t e $\mathrm{r}$ (1978) isolated resistant strains from the water in the flotation dump tanks. Benzimidazole fungicides are still advised to be used before harvest of apples because they are effective in control of Pezicula sp. which also cause apple rot during storage ( $\mathrm{B} \circ \mathrm{r} \mathrm{e} \mathrm{c} \mathrm{k} \mathrm{a} \mathrm{and} \mathrm{C} \mathrm{e} \mathrm{g} \nmid$ o w s k a, 1973).

The aim of the study presented here was to evaluate the pathogenicity of Botrytis cinerea Pers. isolates to apples in order to find if apples are attacked by a specialized form of the fungus. The reaction to benzimidazole fungicides by different isolates of Botrytis cinerea Pers. among which were some from apples, was also determined. The resistance of the fungus is especially dangerous when it coincides with its strong pathogenicity. For this reason, in these studies it was attempted to check if there is a correlation between the resistance of Botrytis cinerea Pers. isolates to benzimidazoles and their pathogenicity.

\section{MATERIALS AND METHODS}

The experiments were conducted on 80 Botrytis cinerea Pers. isolates from different plants and the air in a cold-storage chamber. The origin of the individual isolates is given in Table 1. After isolation and identification of the fungus, all of the isolates were maintained in test tubes on PDA (Difco). The pathogenicity of the fungus was tested by artificial inoculations• of apples of the 'Cortland' variety which were ripe for consumption. The apple skin was incised with a sterile scalpel. A disk of the mycelium, $5 \mathrm{~mm}$ in diameter, cut from a 5 day-old culture of the fungus on PDA, was applied in the incision. The place of inoculation was protected with foil. The inoculated apples were placed under conditions favorable for development of the fungus, that is, at a temperature of $20^{\circ} \mathrm{C}$ and $90 \%$ relative humidity. Twenty apples were inoculated with each isolate in two places, giving thus 40 inoculation points. The apples were uniform in size. After 4 days of incubation, the diameter and depth of the rot were measured. The volume of the rotted apple tissue, which was more or less conical in shape, served to indicate the degree of pathogenicity. The results were analysed statistically by the variance method, averages were compared using the Duncan Test.

The susceptibility of Botrytis cinerea Pers. to benzimidazole fungicides was studied using 111 isolates, among which were the 80 tested for pathogenicity. The origin of the remaining 31 isolates are given in Table 2 . The isolates were gathered 
Ta b l e 1

The hosts and pathogenicity to apples, expressed as the volume of rotting apple tissue, of various Botrytis cinerea Pers. isolates

\begin{tabular}{|c|c|c|c|}
\hline $\begin{array}{l}\text { Isolate } \\
\text { no. }\end{array}$ & Host & & $\begin{array}{c}\text { Volume of rotting } \\
\text { tissue in } \mathrm{cm}^{3}\end{array}$ \\
\hline 1 & 2 & & 3 \\
\hline 33 & raspberries & & $0.09 \mathrm{a}$ \\
\hline 59 & strawberries & & $0.12 b$ \\
\hline 2 & strawberries & & $0.21 \mathrm{c}$ \\
\hline 37 & raspberries & & $0.33 \mathrm{~d}$ \\
\hline 38 & raspberries & & $0.41 \mathrm{de}$ \\
\hline 48 & tomato & & $0.52 \mathrm{e}$ \\
\hline 26 & raspberries & & $0.53 \mathrm{e}$ \\
\hline 35 & raspberries & & 0.59 ef \\
\hline 50 & tomato & & 0.66 ef \\
\hline 4 & strawberries & & 0.66 ef \\
\hline 63 & blueberry & & 0.67 ef \\
\hline 7 & raspberries & & $0.77 \mathrm{f}$ \\
\hline 3 & raspberries & & $0.81 \mathrm{f}$ \\
\hline 34 & raspberries & & $0.82 \mathrm{f}$ \\
\hline 40 & raspberries & & $1.10 \mathrm{~g}$ \\
\hline 11 & peach & & $1.11 \mathrm{~g}$ \\
\hline 25 & raspberries & & $1.14 \mathrm{~g}$ \\
\hline 29 & raspberries & & $1.20 \mathrm{~g}$ \\
\hline 55 & apple & & $1.27 \mathrm{gh}$ \\
\hline 27 & raspberries & & $1.43 \mathrm{gh}$ \\
\hline 16 & strawberries & & $1.64 \mathrm{~h}$ \\
\hline 5 & raspberries & & $1.65 \mathrm{~h}$ \\
\hline 56 & pear & & $1.67 \mathrm{~h}$ \\
\hline 36 & raspberries & & $1.78 \mathrm{hi}$ \\
\hline 68 & apple & & $2.16 \mathrm{hi}$ \\
\hline 20 & raspberries & & $2.16 \mathrm{hi}$ \\
\hline 61 & apple & $\because$ & $2.18 \mathrm{hi}$ \\
\hline 6 & raspberries & & $2.18 \mathrm{hi}$ \\
\hline 69 & apple & & $2.21 \mathrm{hi}$ \\
\hline 21 & raspberries & & $2.33 \mathrm{i}$ \\
\hline 60 & apple & & $2.37 \mathrm{i}$ \\
\hline 24 & raspberries & & $2.44 \mathrm{i}$ \\
\hline 42 & Saintpaulia & & $2.68 \mathrm{ij}$ \\
\hline 66 & blueberries & & $2.69 \mathrm{ij}$ \\
\hline 39 & raspberries & & $2.73 \mathrm{ij}$ \\
\hline 43 & raspberries & & $2.78 \mathrm{ij}$ \\
\hline 52 & carnation & & $2.85 \mathrm{ij}$ \\
\hline 14 & strawberries & $\cdot$ & $2.86 \mathrm{ij}$ \\
\hline 77 & apple & & $2.86 \mathrm{ij}$ \\
\hline 12 & paprika & . & $2.90 \mathrm{ij}$ \\
\hline 72 & apple & & $2.90 \mathrm{ij}$ \\
\hline
\end{tabular}


Table 1 cont.

\begin{tabular}{|c|c|c|}
\hline 1 & 2 & 3 \\
\hline 15 & strawberries & $3.03 \mathrm{ij}$ \\
\hline 10 & cauliflower & $3.04 \mathrm{ij}$ \\
\hline 28 & raspberries & $3.05 \mathrm{ij}$ \\
\hline 31 & tulip & $3.08 \mathrm{ij}$ \\
\hline 65 & blueberries & $3.16 \mathrm{ij}$ \\
\hline 41 & raspberries & $3.23 \mathrm{ij}$ \\
\hline 53 & pear & $3.48 \mathrm{j}$ \\
\hline 57 & apple tree & $3.53 \mathrm{jk}$ \\
\hline 30 & raspberries & $3.63 \mathrm{jk}$ \\
\hline 70 & apple & $3.70 \mathrm{jk}$ \\
\hline 71 & apple & $3.76 \mathrm{jk}$ \\
\hline 79 & apple & $3.88 \mathrm{jk}$ \\
\hline 80 & apple & $3.91 \mathrm{jk}$ \\
\hline 64 & blueberries & $3.92 \mathrm{jk}$ \\
\hline 1 & strawberries & $3.97 \mathrm{jk}$ \\
\hline 46 & apple & $4.02 \mathrm{jk}$ \\
\hline 58 & rose & $4.16 \mathbf{j k}$ \\
\hline 74 & air from a cold storage chamber & $4.18 \mathrm{jk}$ \\
\hline 8 & onion & $4.18 \mathrm{jk}$ \\
\hline 51 & pear & $4.24 \mathrm{jk}$ \\
\hline 19 & raspberries & $4.31 \mathrm{jk}$ \\
\hline 17 & raspberries & $4.47 \mathrm{jk}$ \\
\hline 32 & raspberries & $4.92 \mathrm{k}$ \\
\hline 13 & apple & $5.22 \mathrm{k}$ \\
\hline 78 & air from a cold storage chamber & $5.30 \mathrm{k}$ \\
\hline 67 & chrysanthemum & $5.39 \mathbf{k}$ \\
\hline 9 & tomato & $5.41 \mathrm{k}$ \\
\hline 44 & apple & $5.44 \mathrm{k}$ \\
\hline 23 & raspberries & $5.45 \mathrm{k}$ \\
\hline 49 & apple & $5.58 \mathrm{k}$ \\
\hline 47 & apple & $5.78 \mathrm{kl}$ \\
\hline 62 & apple & $5.80 \mathrm{kl}$ \\
\hline 75 & apple & $6.04 \mathrm{kl}$ \\
\hline 76 & apple & $6.26 \mathrm{k} 1$ \\
\hline 18 & raspberries & $6.36 \mathrm{kl}$ \\
\hline 45 & apple & $6.37 \mathrm{kl}$ \\
\hline 73 & apple & $6.49 \mathrm{kl}$ \\
\hline 22 & raspberries & $6.53 \mathrm{kl}$ \\
\hline 54 & apple & 7.971 \\
\hline
\end{tabular}

$P=0.05$

taking into account the diversity of the hosts, not the intensity of chemical protection used. All of the isolates were cultured on PDA medium, then tested by poisoning the medium. One fungicide from the benzimidazole group was used in these studies since it has been determined many times that Botrytis cinerea 
resistance to these fungicides is of a cross-resistance type for the whole group of benzimidazole compounds. The fungicide as product (Benlate $50 \mathrm{WP}$ ) was added to PDA (Difco) after its sterilization. The fungicide dose was determined by calculating the amount of active ingredient. Three fungicide concentrations were used: $1 \mathrm{ppm}, 10 \mathrm{ppm}$ and $100 \mathrm{ppm}$. The control was medium without fungicide. These concentrations of fungicide allowed the studied isolates to be classified into one of the four groups of sensitivity to fungicides established by $\mathrm{B}$ o $11 \mathrm{e} \mathrm{n}$ and F u c h s (1970):

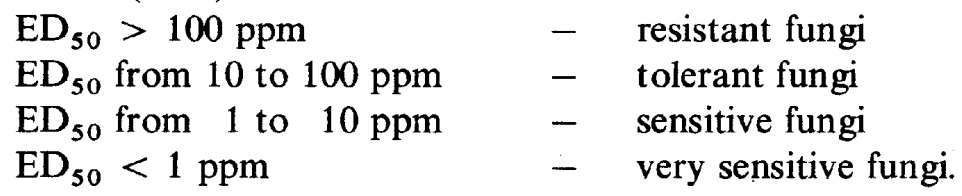

In respect to resistant isolates, two additional concentrations of the fungicide were used $-1000 \mathrm{ppm}$ and $10000 \mathrm{ppm}$. After inoculation of the fungus onto the medium with fungicide and control without fungicide, the dishes were placed at a temperature of $20^{\circ} \mathrm{C}$. Each combination was composed of 5 replications. The diameter of the mycelium was measured after 3-5 days when the control mycelium's diameter was $70 \mathrm{~mm}$.

In order to find if the reaction of Botrytis cinerea Pers. to benzimidazoles is connected with its pathogenicity, the percent of isolates waekly, moderately and strongly pathogenic to apples was calculated for each group of sensitivity to benzimidazole fungicides.

Table 2

The hosts of the remaining 31 Botrytis cinerea Pers. isolates studied for sensitivity to benomyl

\begin{tabular}{ll}
\hline \multicolumn{1}{c}{ Host } & \multicolumn{1}{c}{ Isolate no. } \\
\hline Apple & $81,82,84,85,86,91,98,99,100,101,102,103$, \\
& $105,106,107,108,109,110$ \\
Air in cold storage chamber & $83,96,97$ \\
Blueberry & 87,92 \\
Bean & 88 \\
Black currant & 89 \\
Mallow & 90. \\
Sweet cherry & 93 \\
Plum & 94 \\
Grape & 95 \\
Strawberry & 104 \\
Kale & 111 \\
\hline
\end{tabular}




\section{RESULTS}

The pathogenicity of 80 studied Botrytis cinerea Pers. isolates is presented in Table 1. All of the isolates were pathogenic to 'Cortland' variety apples; in all cases, apple rot took place after inoculation. The isolates differed greatly in their degree of pathogenicity. Statistical analysis discerned 12 classes of significance. The least pathogenic isolate (no. 33) caused $0.09 \mathrm{~cm}^{3}$ of rot whereas the most pathogenic one (no. 54), $7.97 \mathrm{~cm}^{3}$. The pathogenicity of the isolate was not connected with its origin. Isolate from different plants were among both weakly and strongly pathogenic forms.

The isolates were divided into two groups on the basis of their origin, that is, from apples and from other hosts. In order to compare the pathogenicity of apple isolates with the others, three classes of pathogenicity were established:

\begin{tabular}{rcl}
\hline class & volume of rotted tissue & pathogenicity \\
\hline I & $0-2 \mathrm{~cm}^{3}$ & weak \\
II & $2.1-5.0 \mathrm{~cm}^{3}$ & moderate \\
III & $5.1-8.0 \mathrm{~cm}^{3}$ & strong \\
\hline
\end{tabular}

Next, the percentage of isolates belonging to each of the three classes of pathogenicity was calculated in the group of isolates from apples and other hosts (Table 3). A slightly greater pathogenicity of apple isolates was found. Most of the isolates derived from apples belonged to the II and III classes of pathogenicity, only $4.5 \%$ to class I. The isolates from other hosts belonged mainly to classes I and II with only $10.3 \%$ belonging to class III.

The susceptibility of the studied Botrytis cinerea Pers. isolates to benomyl was diverse (Tables 4 and 5). According to the Bollen and Fuchs classification, among the 111 isolates, 67 very sensitive $(60.4 \%), 3$ sensitive $(2.7 \%), 1$ tolerant $(0.9 \%)$ and 40 resistant $(36.0 \%)$ isolates were found. Most of the isolates were either sensitive

\section{T a b l e 3}

Comparison of the pathogenicity to apples of Botrytis cinerea Pers. isolates from apples and from other hosts

\begin{tabular}{lccc}
\hline & \multicolumn{3}{c}{ Isolates in pathogenicity class $(\%)$} \\
\cline { 2 - 4 } Isolates & I & II & III \\
& $\left(0-2.0 \mathrm{~cm}^{3}\right)$ & $\left(2.1-5.0 \mathrm{~cm}^{3}\right)$ & $\left(5.1-8.0 \mathrm{~cm}^{3}\right)$ \\
\hline From apples & 4.5 & 50.0 & 45.5 \\
From other hosts & 39.7 & 50.0 & 10.3 \\
\hline
\end{tabular}


Ta b le 4

Susceptibility to benomyl of Botrytis cinerea Pers. isolates from apples

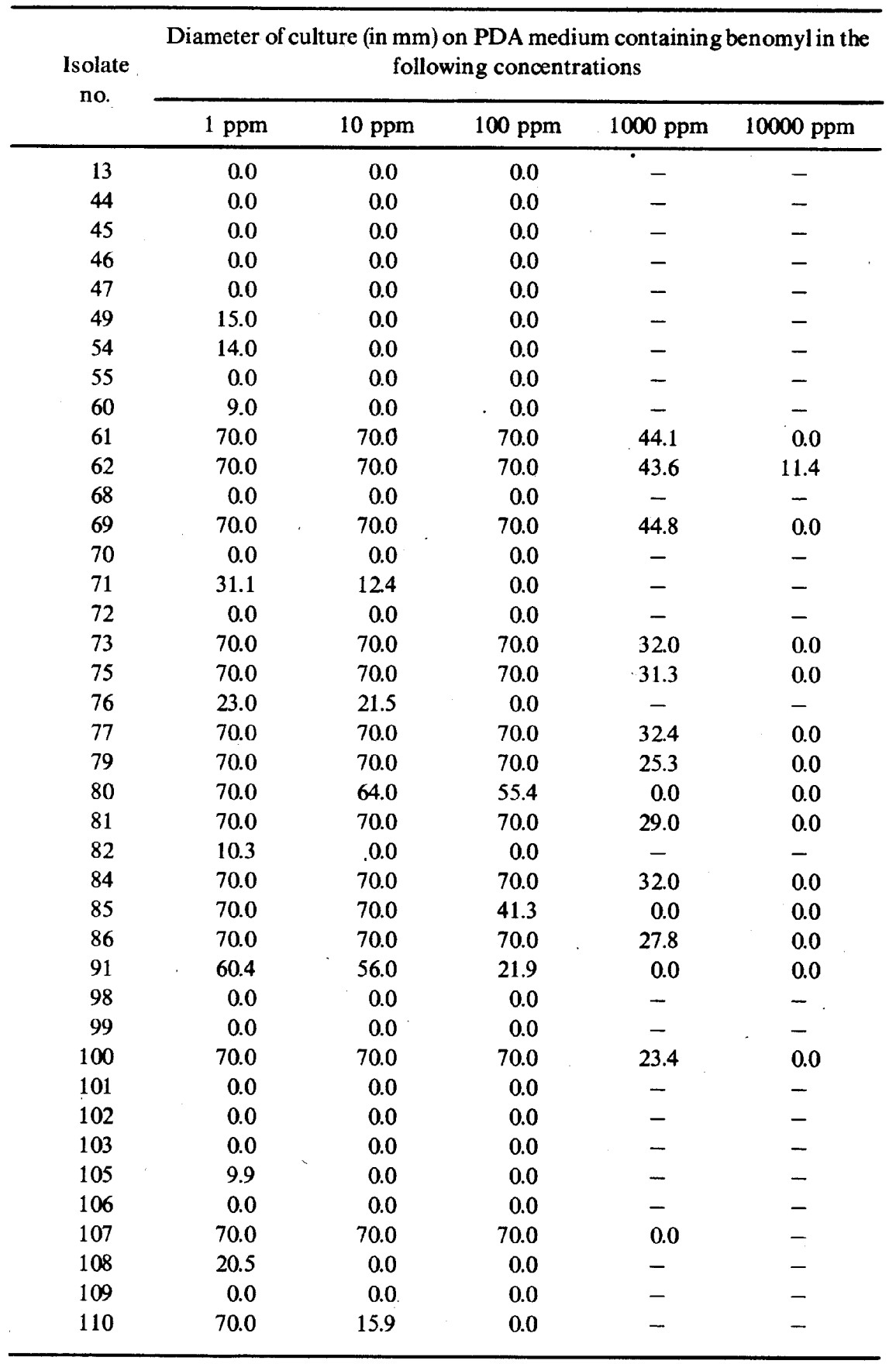


H. Bryk

Ta b l e 5

Susceptibility to benomyl of Botrytis cinerea Pers. isolates from different hosts

Diameter of culture (in mm) of PDA medium containing benomyl in the Isolate following concentrations

\begin{tabular}{|c|c|c|c|c|c|}
\hline & 1 ppm & $10 \mathrm{ppm}$ & $100 \mathrm{ppm}$ & $1000 \mathrm{ppm}$ & $10000 \mathrm{ppm}$ \\
\hline 1 & 2 & 3 & 4 & 5 & 6 \\
\hline 1 & 70.0 & 70.0 & 54.4 & 6.7 & 0.0 \\
\hline 2 & 0.0 & 0.0 & 0.0 & - & - \\
\hline 3 & 0.0 & 0.0 & 0.0 & - & - \\
\hline 4 & 0.0 & 0.0 & 0.0 & - & - \\
\hline 5 & 0.0 & 0.0 & 0.0 & - & - \\
\hline 6 & 70.0 & 70.0 & 70.0 & 21.7 & 0.0 \\
\hline 7 & 0.0 & 0.0 & 0.0 & - & - \\
\hline 8 & 70.0 & 70.0 & 65.5 & 0 & - \\
\hline 9 & 0.0 & 0.0 & 0.0 & - & - \\
\hline 10 & 0.0 & 0.0 & 0.0 & - & - \\
\hline 11 & 0.0 & 0.0 & 0.0 & - & - \\
\hline 12 & 0.0 & 0.0 & 0.0 & - & - \\
\hline 14 & 0.0 & 0.0 & 0.0 & - & - \\
\hline 15 & 0.0 & 0.0 & 0.0 & - & - \\
\hline 16 & 0.0 & 0.0 & 0.0 & - & - \\
\hline 17 & 70.0 & 70.0 & 57.1 & 32.2 & 0.0 \\
\hline 18 & 70.0 & 70.0 & 70.0 & 0 & 0.0 \\
\hline 19 & 70.0 & 70.0 & 70.0 & 16.4 & 0.0 \\
\hline 20 & 70.0 & 70.0 & 58.7 & 8.6 & 0.0 \\
\hline 21 & 70.0 & 70.0 & 57.5 & 24.0 & 0.0 \\
\hline 22 & 70.0 & 70.0 & 70.0 & 40.2 & 0.0 \\
\hline 23 & 70.0 & 70.0 & 70.0 & 31.7 & 0.0 \\
\hline 24 & 70.0 & 70.0 & 70.0 & 10.6 & 0.0 \\
\hline 25 & 0.0 & 0.0 & 0.0 & - & - \\
\hline 26 & 70.0 & 70.0 & 57.2 & 225 & 0.0 \\
\hline 27 & 70.0 & 68.0 & 61.9 & 8.3 & 0.0 \\
\hline 28 & 0.0 & 0.0 & 0.0 & - & - \\
\hline 29 & 70.0 & 70.0 & 70.0 & 0.0 & 0.0 \\
\hline 30 & 0.0 & 0.0 & 0.0 & - & - \\
\hline 31 & 70.0 & 70.0 & 56.1 & 0.0 & 0.0 \\
\hline 32 & 0.0 & 0.0 & 0.0 & - & - \\
\hline 33 & 70.0 & 70.0 & 58.3 & 0.0 & 0.0 \\
\hline 34 & 40.1 & 13.7 & 0.0 & - & - \\
\hline 35 & 15.5 & 0.0 & 0.0 & - & - \\
\hline 36 & 0.0 & 0.0 & 0.0 & - & - \\
\hline 37 & 70.0 & 70.0 & 51.3 & 8.5 & 0.0 \\
\hline 38 & 70.0 & 70.0 & 60.1 & 0.0 & 0.0 \\
\hline 39 & 70.0 & 26.5 & 0.0 & - & - \\
\hline 40 & 70.0 & 70.0 & 70.0 & 0.0 & 0.0 \\
\hline
\end{tabular}


Table 5 cont.

\begin{tabular}{|c|c|c|c|c|c|}
\hline 1 & 2 & 3 & 4 & 5 & 6 \\
\hline 41 & 70.0 & 70.0 & 70.0 & 9.8 & 0.0 \\
\hline 42 & 25.2 & 0.0 & 0.0 & - & - \\
\hline 43 & 0.0 & 0.0 & 0.0 & - & - \\
\hline 48 & 70.0 & 70.0 & 70.0 & 37.1 & 0.0 \\
\hline 50 & 70.0 & 70.0 & 70.0 & 0.0 & 0.0 \\
\hline 51 & 0.0 & 0.0 & 0.0 & - & - \\
\hline 52 & 0.0 & 0.0 & 0.0 & - & - \\
\hline 53 & 0.0 & 0.0 & 0.0 & - & - \\
\hline 56 & 0.0 & 0.0 & 0.0 & - & - \\
\hline 57 & 0.0 & 0.0 & 0.0 & - & - \\
\hline 58 & 70.0 & 70.0 & 70.0 & 0.0 & 0.0 \\
\hline 59 & 0.0 & 0.0 & 0.0 & - & - \\
\hline 63 & 0.0 & 0.0 & 0.0 & - & - \\
\hline 64 & 0.0 & 0.0 & 0.0 & - & - \\
\hline 65 & 0.0 & 0.0 & 0.0 & - & - \\
\hline 66 & 0.0 & 0.0 & 0.0 & - & - \\
\hline 67 & 0.0 & 0.0 & 0.0 & - & - \\
\hline 74 & 70.0 & 70.0 & 70.0 & 42.0 & 0.0 \\
\hline 78 & 70.0 & 70.0 & 70.0 & 18.0 & 0.0 \\
\hline 83 & 0.0 & 0.0 & 0.0 & - & - \\
\hline 87 & 0.0 & 0.0 & 0.0 & - & - \\
\hline 88 & 13.5 & 0.0 & 0.0 & - & - \\
\hline 89 & 0.0 & 0.0 & 0.0 & - & - \\
\hline 90 & 0.0 & 0.0 & 0.0 & - & - \\
\hline 92 & 0.0 & 0.0 & 0.0 & - & - \\
\hline 93 & 0.0 & 0.0 & 0.0 & - & - \\
\hline 94 & 0.0 & 0.0 & 0.0 & - & - \\
\hline 95 & 0.0 & 0.0 & 0.0 & - & - \\
\hline 96 & 0.0 & 0.0 & 0.0 & - & - \\
\hline 97 & 0.0 & 0.0 & 0.0 & - & - \\
\hline 104 & 0.0 & 0.0 & 0.0 & - & - \\
\hline 111 & 70.0 & 70.0 & 61.6 & 30.5 & 0.0 \\
\hline
\end{tabular}

Ta b le 6

Comparison of the sensitivity to ben omyl of Botrytis cinerea Pers. isolates from apples with that of isolates from other hosts

\begin{tabular}{ccc}
\hline $\begin{array}{c}\text { Sensitivity to } \\
\text { benomyl class }\end{array}$ & $\begin{array}{c}\text { Isolates from } \\
\text { apples } \\
\text { (40 isolates) }\end{array}$ & $\begin{array}{c}\text { Isolates from } \\
\text { other hosts } \\
\text { (71 isolates) }\end{array}$ \\
\hline I (very sensitive) & $60.0 \%$ & $60.6 \%$ \\
II (sensitive) & $2.5 \%$ & $2.8 \%$ \\
III (tolerant) & $2.5 \%$ & $0.0 \%$ \\
IV (resistant) & $35.0 \%$ & $36.6 \%$ \\
\hline
\end{tabular}


or resistant, intermediate forms were few. Six isolates exhibited a very high degree of resistance, $\mathrm{ED}_{50}$ for them exceeded $1000 \mathrm{ppm}$ benomyl.

A comparison of the sensitivity to benomyl of isolates from apples with the remaining ones is presented in Table 6. Both in the group of isolates from apples and that from other hosts, the proportion between resistant and sensitive to benomyl isolates was similar. In both groups, approximately $1 / 3$ of the isolates were resistant.

The pathogenicity of 80 isolates to apples was compared with their reaction to benomyl, and the percenage of isolates of different pathogenicity in the classes very sensitive and resistant to benomyl, was calculated. The II and III class of sensitivity to benomyl were not taken into account because no isolate was found in the class III and only 2 isolates were found in class II. It was found that resistance to benomyl was not correlated with a greater pathogenicity of the fungus (Table 7). Highly pathogenic forms made up $21.2 \%$ of those isolates resistant to benomyl and $20.0 \%$ of those very sensitive to it. In both groups, almost half of the isolates were of moderate pathogenicity.

Ta b 1 e 7

Comparison of the pathogenicity of Botrytis cinerea Pers. to apples with its sensitivity to benzimidazole fungicides

\begin{tabular}{cccc}
\hline \multirow{2}{*}{$\begin{array}{c}\text { Sensitivity to } \\
\text { benomyl class }\end{array}$} & \multicolumn{3}{c}{ Isolates in pathogenicity class $\%)$} \\
\cline { 2 - 4 } & $\begin{array}{c}\text { I } \\
\left(0-2.0 \mathrm{~cm}^{3}\right)\end{array}$ & $\begin{array}{c}\text { II } \\
\left(2.1-5.0 \mathrm{~cm}^{3}\right)\end{array}$ & $\begin{array}{c}\text { III } \\
\left(5.1-8.0 \mathrm{~cm}^{3}\right)\end{array}$ \\
\hline $\mathrm{I}-\begin{array}{c}\text { very sensitive } \\
\text { isolates }\end{array}$ & 31.1 & 48.9 & 20.0 \\
II $-\begin{array}{c}\text { resistant } \\
\text { isolates }\end{array}$ & 27.3 & 51.5 & 21.2 \\
\hline
\end{tabular}

\section{DISCUSSION}

The variability of the fungus, Botrytis cinerea Pers., has been the subject of study for many years, however, a uniform opinion on the parasitic specialization of this fungus has not been reached yet. Some authors have found parasitic speoialization to some degree ( $\mathrm{D} \mathrm{u} \mathrm{b}$ o s and B u l i t, 1973), in the opinion of others ( $\mathrm{S} \mathrm{ch} \mathrm{nell} \mathrm{hardt}$ and $\mathrm{He} \mathrm{a} \mathrm{ld,} \mathrm{1936)} \mathrm{no} \mathrm{such} \mathrm{specialization}$ exists.

In this study it has been found that isolates from apples exbihited moderate or strong pathogenicity to apples. However, a weakly pathogenic apple isolate no. 55 - belonging to class I of pathogenicity was found. This does not allow the thesis on parasitic specialization' of the fungus to be confirmed. 
All of the isolates were pathogenic to apples; regardless of its origin, the fungus caused apple rot. Since the Botrytis cinerea Pers. is a very common species the high possibility of apples infections may be expected.

A very high degree of variability of pathogenicity of the fungus to apples was shown. This is probably caused by different enzymatic activity of the individual isolates. W a s f y et al. (1978) and D i L e $\mathrm{n} \mathrm{n}$ a et al. (1981) found a clear correlation between the pathogenicity of an isolate and the production of enzymes by it, mainly of polygalacturonase which plays a role in the maceration of apple tissue.

As a result of the studies conducted here, it was found that the susceptibility of Botrytis cinerea Pers. to benomyl. and therefore to the whole group of benzimidazole fungicides, is very differentiated. From the 111 isolates, $36 \%$ were resistant, $60.4 \%$ were very sensitive. Among the Botrytis cinerea Pers. isolates from apples, $35 \%$ were resistant. One isolate showed an extremely high degree of resistance - it even grew on a medium containing $10000 \mathrm{ppm}$ benomyl. Finding that only $35 \%$ of the isolates from apples are resistant indicates that, in spite of continuous use of these fungicides, the entire Botrytis cinerea Pers. population on apples has not become resistant.

The correlation of resistance to fungicides with a high pathogenicity of the fungus would create a dangerous situation for stored fruit because forms such as these could gain dominance in the population and eliminate the sensitive forms of the fungus. In the studies presented here, it has been shown that the pathogenicity of the isolate is not correlated with its reaction to benomyl. A similar observation had been made by B e r t r a d and S a u li e-C a r te r (1978).

\section{REFERENCES}

A r s e n i u k E., B r y k H., 1978. Odporność grzyba Botryótinia fuckeliana (de Bary) Whetzel (Botrytis cinerea Pers.) - patogena malin, truskawek i innych roślin uprawnych na fungicydy benzimidazolowe. Acta Agrobot. 31: 205-220.

B e $r \mathrm{t} r$ a $\mathrm{nd}$ P.F., S a u $\mathrm{l}$ i e-C a $\mathrm{r} \mathrm{t}$ e $\mathrm{r}$ J. L., 1978. The occurence of benomyl-tolerant strains of Penicillium expansum and Botrytis cinerea in the Mid-Columbia Region of Oregon and Washington. Plant Dis. Rep. 62: 302-305.

B o $11 \mathrm{e}$ n G. J., F u c h s A., 1970. On the specifity of the in vitro and in vivo antifungal activity of benomyl. Neth. J. Pl. Path. 76: 299-312.

B o r e ck a H., C e g ł o w s k a L., 1973. Zwalczanie gorzkiej zgnilizny jabłek. Część I. Skuteczność fungicydów i programów opryskiwań. Pr. Inst. Sad. 17: 217-221.

D i L e n n a P., M a r c i a n o P., M a g r o P., 1981. Comparative investigation on morphological and physiological features of three isolates of Botrytis cinerea. Phytopath. Z. 100: 203-211.

D u b o s B., B u 1 i t J., 1973. Study of the variability of Botrytis cinerea Pers. isolated from the vine. Botrytis Meeting, Warszawa. Pr. Inst. Sad., Ser. E 2: 1-12.

G j a e r u m H. B., 1978. Benomyl-og thiophanattolerant graskimmel isolert fra begerrate $\mathrm{i}$ eple. Gartneryrket $68: 477-478$. 
G r i m m ·R., 1977. Die Apfel-Kelchfäule und ihre Bekämpfung. Schweił Z. Obst. Weinbau. 2: 33-37.

I 1 e v a E., 1977. V'trevid ovo raznoobraze pri Botrytis cinerea Pers. - prichinitel na sivoto gnene po oranzherinite domati. Grad. Loz. Nauka. 14: 52-59.

M a c N e i 1 B. H., 1953. A Botrytis root rot condition in lettuce. Plant Dis. Rep. 37: 618-619.

M a r r a s F., 1960. Determinizione di tre "razze" di Botrytis cinerea Pers. isolate in Sardegna di pomodoro, lattuga e basilico. Stud. Sassa. 8: 62-78.

P e y e r E., 1963. Stielfaule und Stiehöhne bei den Traubèn. Schweiz. Z. Obst. Weinbau. 72: 70-72 S a d o w s k i S., 1971. Badania patogeniczności kilku szczepów grzyba Botrytis cinerea Pers. na lnie. Zesz. Nauk. WSR Olszytn 27: 251-258.

$\mathrm{Schne} 11 \mathrm{~h}$ a rdt O., He a $1 \mathrm{~d}$ F. D., 1936. Pathogenicity tests with Botrytis spp. when inoculated into apples. Phytopath. 26: 786-794.

W a s f y E. H., F a $r$ a $g$ S. A., T a $r$ a b i e h M. A., A b d-E 1 m o e t y S. H., 1978. Studies on enzymes of different strains of Botrytis cinerea. Phytopath. Z. 92: 168-179.

Patogeniczność różnych izolatów Botrytis cinerea Pers. w stosunku do jabłek $i$ ich reakcja na fungicydy benzimidazolowe

\section{St reszcze ni e}

Badano patogeniczność 80 izolatów Botrytis cinerea Pers., wyizolowanych z różnych gospodarzy, w stosunku do jablek. Nie stwierdzono specjalizacji pasożytnictwa grzyba. Wszystkie izolaty, niezależnie od swojego pochodzenia, powodowały gnicie jabłek. Patogenicznó́ć izolatów była bardzo zróżnicowana. Izolaty pochodzące z jablek były średnio i silnie patogeniczne dla jabłek, tylko 1 izolat (na 22 badane) byl słabo patogeniczny.

Badano reakcję na benomyl izolatów pochodzących z jablek i z innych gospodarzy. 35\% izolatów pochodzących z jabłek było odpornych na benomyl. Nie stwierdzono związku między patogenicznością izolatu a jego reakcją na benomyl. 